\title{
Molecular evidence of Culex pipiens form molestus and hybrids pipiens/molestus in Morocco, North Africa
}

\author{
Fadila Amraoui ${ }^{1,2}$, Mhamed Tijane ${ }^{2}$, Mhammed Sarih ${ }^{1}$ and Anna-Bella Failloux ${ }^{3^{*}}$
}

\begin{abstract}
Background: Culex pipiens L. is the most widespread mosquito vector in temperate regions including North Africa. Cx. pipiens has two recognized forms or biotypes; pipiens and molestus are morphologically indistinguishable with distinct behavior and physiology that may influence their vectorial status. In our study, we prospected for the different forms of $C x$. pipiens in Morocco.

Methods: Cx. pipiens larvae were collected in 9 sites throughout Morocco during summer 2010 and reared until imago stage. CX. pipiens was identified using diagnostic primers designed for the flanking region of microsatellite CQ11.

Results: We established the presence of both forms of $C$ x. pipiens and their hybrids in Morocco.

Conclusions: Molecular identification provides the first evidence of the presence of $C$ x. pipiens form molestus in Morocco and hybrids between pipiens and molestus forms in North Africa. The epidemiological implications of our findings are discussed.
\end{abstract}

Keywords: Culex pipiens complex, Microsatellite, Molecular taxonomy, Morocco, North Africa

\section{Background}

The Culex pipiens complex includes several species; $C x$. pipiens pipiens Linnaeus, 1758 and $C x$. pipiens quinquefasciatus Say, 1823 are the most ubiquitous mosquitoes in temperate and tropical regions, respectively. $C x . p$. pipiens has two distinct forms or biotypes: form pipiens and form molestus which are morphologically indistinguishable and differ in physiology and behavior. Cx. pipiens form pipiens is subjected to diapause (heterodynamic), is anautogeneous (only lays eggs after a blood-meal), and eurygamous (unable to mate in confined spaces). On the other hand, $C x$. pipiens form molestus Forskal, 1775 does not diapause (homodynamic), is autogeneous (lays first batch of eggs without taking a blood-meal) and stenogamous (mates in confined spaces) [1,2]. In addition, the biotypes molestus and pipiens occupy distinct habitats in Russia and the northeastern United States. Indeed, molestus form occurs in underground areas in urban settings while pipiens form lives aboveground [3,4]. In Europe, sympatric occurrence of

\footnotetext{
* Correspondence: anna-bella.failloux@pasteur.fr

${ }^{3}$ Institut Pasteur, Department of Virology, Arboviruses and Insect Vectors,

25-28 rue du Docteur Roux, Paris 75724, France

Full list of author information is available at the end of the article
}

both biotypes has been observed in aboveground habitats as well as in underground habitats [5-7]. The two forms did not seem to be genetically isolated and were reported to hybridize in the United States and Europe [6-8]. They have different trophic preferences: pipiens biting mainly birds and molestus feeding on mammals, whereas hybrids exhibit an opportunistic behavior and can readily feed on both hosts. These feeding patterns are thought to influence the transmission of avian and mammalian pathogens.

In North Africa, $C x . p$. pipiens is a competent vector of several pathogens infecting animals and humans including West Nile virus [9], Rift Valley Fever virus [10-12] and filarial worms [13-16]. Based on morphological characters, behavioral and reproductive specializations, the mosquito $C x . p$. pipiens was described in the North African region [17-25]. Nevertheless, these classical characters present limited value. Therefore, our study aims to identify members of the Cx. pipiens complex present in Morocco based on a molecular identification.

\section{Methods}

Mosquitoes were collected as larvae using the "dipping" sampling method during summer 2010 from three 


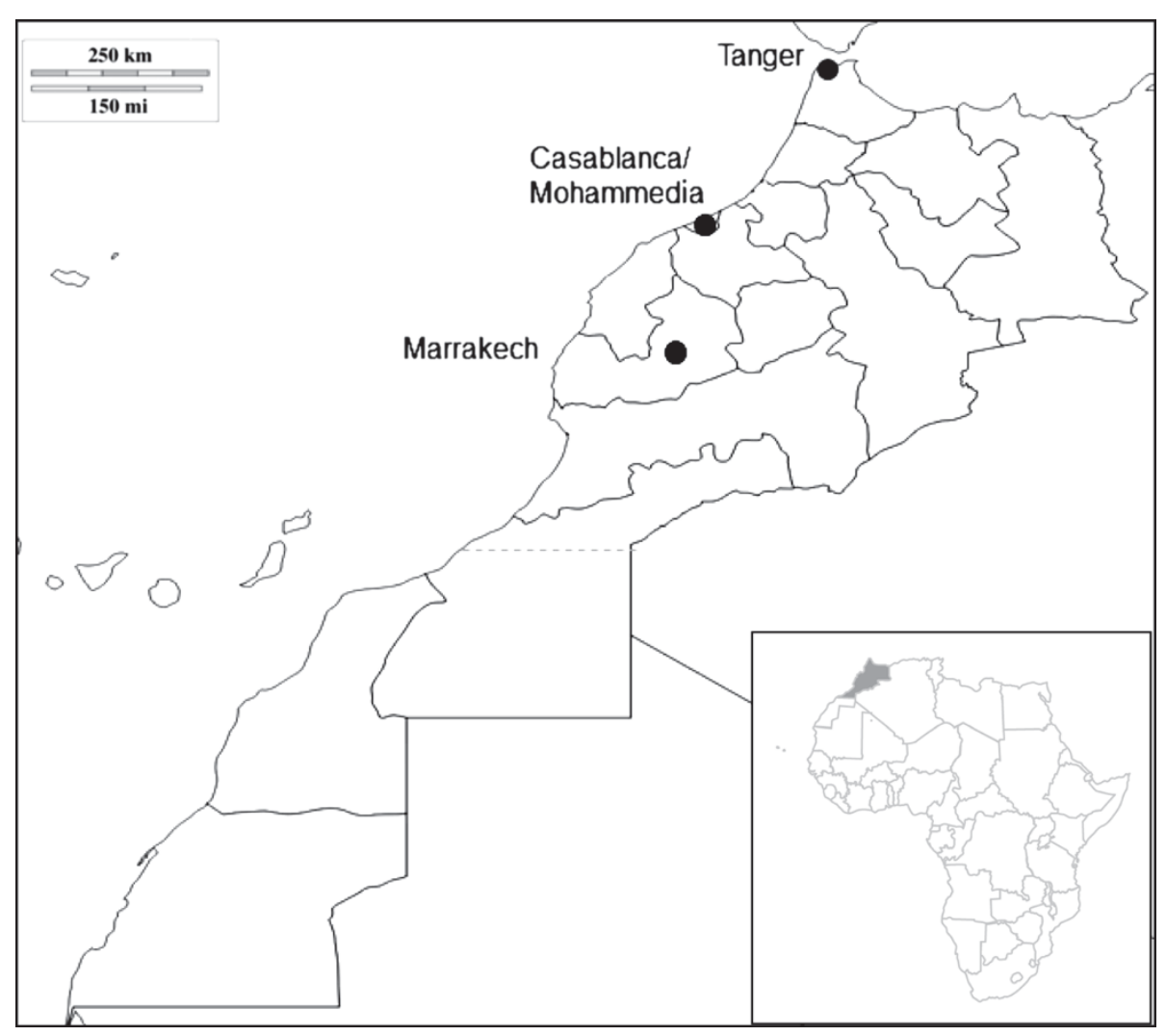

Figure 1 Localization of the collection sites in Morocco.

Moroccan regions (Figure 1). A total of 9 sites were classified according to the habitat (urban, suburban or rural) and the type of breeding site (aboveground or underground). Fourth instar larvae were used for morphological identification [26] and reared until imago stage at $28 \pm 1{ }^{\circ} \mathrm{C}$ with $80 \%$ relative humidity and a $16 \mathrm{~h}: 8 \mathrm{~h}$ photoperiod. Emerged adults were conserved at $-20^{\circ} \mathrm{C}$ for subsequent molecular characterization.

DNA extraction from F0 individuals was performed using the method of DNAzol as described in the manufacturer's protocol. Specimens were identified as belonging to the Culex pipiens complex using a multiplex PCR assay described in Bahnck and Fonseca (2006) [27]. The locus CQ11 was used to distinguish between the two forms of $C x$. pipiens. The DNA fragment size amplified varied between pipiens and molestus allowing us to distinguish the two forms in a single PCR reaction (Figure 2). Specimens of $C x$. pipiens molestus from Japan were used as control.

\section{Results and Discussion}

A total of 214 adults were characterized by PCR and frequencies of different forms are represented in Table 1. Overall, 52.3\% of adults tested were homozygous for the 200 bp fragment which is characteristic of the pipiens form, $22 \%$ were homozygous for the $250 \mathrm{bp}$ fragment identifying the molestus form and the remaining (25.7\%) corresponded to hybrids.

This study provides the first molecular evidence for the presence of $C x$. pipiens form molestus in Morocco and hybrids in North Africa.

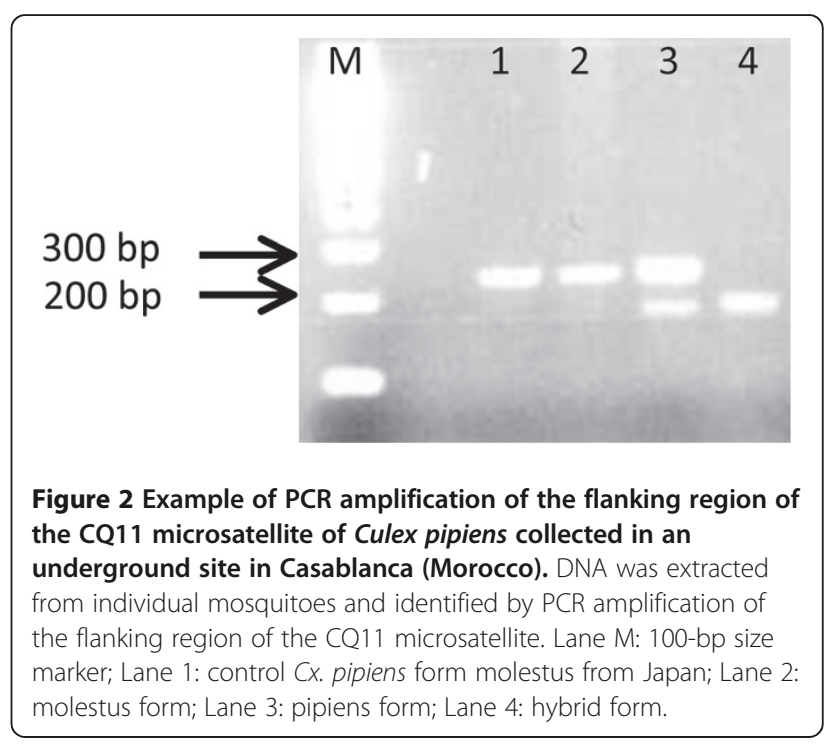


Table 1 Frequency of forms of the Culex pipiens complex in Morocco

\begin{tabular}{cccccc}
\hline City & Habitat & $\begin{array}{c}\text { Breeding site } \\
\text { (Ground) }\end{array}$ & $\begin{array}{c}\text { Pipiens } \\
\text { form (\%) }\end{array}$ & $\begin{array}{c}\text { Molestus } \\
\text { form (\%) }\end{array}$ & $\begin{array}{c}\text { Hybrids } \\
\text { (\%) }\end{array}$ \\
\hline Tanger & Urban & Above & $69.6(16)$ & $8.7(2)$ & $21.7(5)$ \\
& Sub-urban & Above & $52.2(12)$ & $34.8(8)$ & $13(3)$ \\
& Rural & Above & $62.5(15)$ & $8.3(2)$ & $29.2(7)$ \\
Casablanca/ & Urban & Above & $31(9)$ & $17.2(5)$ & $51.8(15)$ \\
Mohammedia & Urban & Under & $25(8)$ & $59.4(19)$ & $15.6(5)$ \\
& Sub-urban & Above & $53.6(15)$ & $17.8(5)$ & $28.6(8)$ \\
Marrakech & Sub-urban & Above & $60.9(14)$ & $8.7(2)$ & $30.4(7)$ \\
& Rural & Above & $78.3(18)$ & $4.3(1)$ & $17.4(4)$ \\
& Rural & Under & $55.6(5)$ & $33.3(3)$ & $11.1(1)$ \\
\hline
\end{tabular}

Cx.pipiens larvae were collected at various sites in Morocco, reared to adults and identified by PCR amplification of the flanking region of the CQ11 microsatellite. In brackets, number of tested mosquitoes.

The molestus form has been described as a distinct species, Cx. molestus Forskal, 1775 from autogeneous Egyptian specimens. Because $C x$. pipiens form molestus is stenogamous and autogenous, it colonizes underground areas in urban settings [3] with limited geographic distribution throughout the world. In our study, $C x$. pipiens form pipiens and form molestus were found in urban, suburban and rural habitats. Indistinctly, the two forms co-occur in aboveground and underground breeding sites. Sympatric distribution of the biotypes molestus and pipiens in surface breeding sites has been observed in southern Europe and the United States [5,6,8] and in underground breeding sites in North Europe [7].

\section{Conclusions}

Until now, hybrids were mainly reported in the United States $[4,8]$ and South Europe [6]. Our findings corroborate the presence of hybrids in all breeding sites sampled. Hybrids between molestus and pipiens forms are considered of great epidemiological importance. They exhibit intermediate physiological and behavioral traits [28] and can readily feed on avian and mammalian hosts $[8,29]$. This opportunistic biting behavior will potentiate the role of Cx. pipiens as a bridge-vector for the transmission of pathogens such as West Nile virus, from birds (amplification hosts) to humans $[8,30]$.

\section{Competing interests}

The authors declare that they have no competing interests.

\section{Acknowledgments}

We thank Laurence Mousson for technical help. FA was supported by the "Division Internationale" of the Institut Pasteur. This work was funded by the Institut Pasteur (ACIP grant A-08-2009) and the European Commission Framework Program Seven Award "InfraVec".

\section{Author details}

${ }^{1}$ Institut Pasteur du Maroc, Laboratoire des Maladies Vectorielles, 1 Place Louis Pasteur, Casablanca 20360, Morocco. ${ }^{2}$ Faculté des Sciences, Laboratoire de Biochimie et Immunologie, 4 avenue Ibn Battouta, Rabat BP 1014 RP, Morocco. ${ }^{3}$ Institut Pasteur, Department of Virology, Arboviruses and Insect Vectors, 25-28 rue du Docteur Roux, Paris 75724, France.

\section{Authors'contributions}

FA carried out mosquito genotyping, contributed to the interpretation of results and drafted the manuscript. MT participated in the design of experiments. MS participated in the design of experiments and mosquito collections. ABF designed the experiments and drafted the manuscript. All authors read and approved the final manuscript.

Received: 11 March 2012 Accepted: 27 April 2012

Published: 27 April 2012

References

1. Harbach RE, Harrison BA, Gad AM: Culex (Culex) molestus Forskal (Diptera: Culicidae): Neotype designation, description, variation, and taxonomic status. Proc Entomol Soc Wash 1984, 86:521-542.

2. Harbach RE, Dahl C, White GB: Culex (Culex) pipiens Linnaeus (Diptera, Culicidae) - concepts, type designations, and description. Proc Entomol Soc Wash 1985, 87:1-24.

3. Byrne K, Nichols RA: Culex pipiens in London Underground tunnels: differentiation between surface and subterranean populations. Heredity 1999, 82:-15

4. Huang S, Molaei G, Andreadis TG: Genetic insights into the population structure of Culex pipiens (Diptera: Culicidae) in the Northeastern United States by using microsatellite analysis. AmJTrop Med Hyg 2008, 79:518-527.

5. Chevillon C, Eritja R, Pasteur N, Raymond M: Commensalism, adaptation and gene flow: mosquitoes of the Culex pipiens complex in different habitats. Genet Res 1995, 66:147-157.

6. Gomes B, Sousa CA, Novo MT, Freitas FB, Alves R, Côrte-Real AR, Salgueiro P, Donnelly MJ, Almeida AP, Pinto J: Asymmetric introgression between sympatric molestus and pipiens forms of Culex pipiens (Diptera: Culicidae) in the Comporta region, Portugal. BMC Evol Biol 2009, 9:262.

7. Reusken CBEM, de Vries A, Buijs J, Braks MAH, den Hartog W, Scholte EJ: First evidence for presence of Culex pipiens biotype molestus in the Netherlands, and of hybrid biotype pipiens and molestus in northern Europe. J Vector Ecol 2010, 35:210-212.

8. Fonseca DM, Keyghobadi N, Malcolm CA, Mehmet C, Schaffner F, Mogi M, Fleischer RC, Wilkerson RC: Emerging vectors in the Culex pipiens complex. Science 2004, 303:1535-1538.

9. Krida G, Diancourt L, Bouattour A, Rhim A, Chermiti B, Failloux AB: Assessment of the risk of introduction to Tunisia of the Rift Valley fever virus by the mosquito Culex pipiens. Bull Soc Pathol Exot 2011, 104:250-259.

10. Hoogstraal H, Meegan JM, Khalil GM, Adham FK: The Rift Valley fever epizootic in Egypt 1977-78. 2. Ecological and entomological studies. Trans R Soc Trop Med Hyg 1979, 73:624-629.

11. Meegan JM, Khalil GM, Hoogstraal H, Adham FK: Experimental transmission and field isolation studies implicating Culex pipiens as a vector of Rift Valley fever virus in Egypt. Am JTrop Med Hyg 1980, 29:1405-1410.

12. Moutailler S, Krida G, Schaffner F, Vazeille M, Failloux AB: Potential vectors of Rift Valley fever virus in the Mediterranean Region. Vector Borne Zoonot Dis 2008, 8:749-753.

13. Harb M, Faris R, Gad AM, Hafez ON, Ramzi R, Buck AA: The resurgence of lymphatic filariasis in the Nile Delta. Bull WHO 1993, 71:49-54.

14. Krida G, Bouattour A, Rodhain F, Failloux AB: Variability among Tunisian populations of Culex pipiens: genetic structure and susceptibility to a filarial parasite, Brugia pahangi. Parasitol Res 1998, 84:139-142.

15. Abdel-Hamid YM, Soliman MI, Allam KM: Spatial distribution and abundance of culicine mosquitoes in relation to the risk of filariasis transmission in El Sharqiya Governorate, Egypt. Egypt Acad J Biolog Sci 2009, 1:39-48.

16. Abdel-Hamid YM, Soliman MI, kenawy MA: Mosquitoes (Diptera: Culicidae) in relation to the risk of disease transmission in El Ismailia governorate, Egypt. J Egypt Soc Parasitol 2011, 41:109-118.

17. Roubaud E: Le pouvoir autogène chez le biotype nord-africain du moustique commun Culex pipiens (L.). Bull Soc Path Exot 1939, 36:172-175.

18. Knight KL, Malek AA: A morphological and biological study of Culex pipiens in the Cairo area of Egypt. Bull Soc Fouad I Entomol 1951, 35:175-185.

19. Gaud J: Notes biogéographiques sur les Culicidés du Maroc. Arch Inst Pasteur Maroc 1953, 4:443-490. 
20. Vermeil C: Nouvelle contribution à l'étude du complexe Culex pipiens en Tunisie. Bull Soc Pathol Exot 1954, 47:841-843.

21. Rioux JA: Les culicidés du "midi" méditerranéen. Paris: Lechevalier; 1958.

22. Senevet G, Andarelli L, Graells R: A propos de Culex pipiens en Algérie. Arch Inst Pasteur Algérie 1958, 36:70-74.

23. Rioux $J A$, Juminer $B$, Kchouk $M$, Croset $H$ : Présence du caractère autogène chez Culex pipiens pipiens L. dans un biotope épigé de l'lle de Djerba. Arch Inst Pasteur Tunis 1965, 42:1-8.

24. Pasteur N, Rioux JA, Guilvard E, Pech-Perières J: Nouvelle mention, pour le "Midi" méditerranéen, de populations naturelles anautogènes et sténogames de Culex pipiens pipiens L. Ann Parasitol Hum Comp 1977, 52:205-210

25. Himmi O, Dakki M, Trari B, El Agbani MA: Les Culicidae du Maroc: clés d'identification, avec données biologiques et écologiques. Trav Inst Sci, Série Zool Rabat 1995, 44:51.

26. Brunhes J, Rhaim A, Geoffroy B, Angel G, Hervy JP: Les moustiques de I'Afrique méditerranéenne. Logiciel d'identification et d'enseignement. Montpellier, France: IRD \& IPT, CD-Rom collection didactique, Éditions IRD; 2000.

27. Bahnk CM, Fonseca DM: Rapid assay to identify the two genetic forms of Culex (Culex) pipiens L. (Diptera: Culicidae) and hybrid populations. AmJTrop Med Hyg 2006, 75:251-255.

28. Spielman A: Structure and seasonality of Nearctic Culex pipiens populations. Ann NY Acad Sci 2001, 951:220-234.

29. Kilpatrick AM, Kramer LD, Jones MJ, Marra PP, Daszak P, Fonseca DM: Genetic influences on mosquito feeding behavior and the emergence of zoonotic pathogens. AmJTrop Med Hyg 2007, 77:667-671.

30. Hamer GL, Kitron UD, Brawn JD, Loss SR, Ruiz MO, Goldberg TL, Walker ED: Culex pipiens (Diptera: Culicidae): a bridge vector of West Niles Virus to humans. J Med Entomol 2008, 45:125-128.

doi:10.1186/1756-3305-5-83

Cite this article as: Amraoui et al:: Molecular evidence of Culex pipiens form molestus and hybrids pipiens/molestus in Morocco, North Africa. Parasites \& Vectors 2012 5:83.

\section{Submit your next manuscript to BioMed Central and take full advantage of:}

- Convenient online submission

- Thorough peer review

- No space constraints or color figure charges

- Immediate publication on acceptance

- Inclusion in PubMed, CAS, Scopus and Google Scholar

- Research which is freely available for redistribution 